Available online at http://journal.stkip-andi-matappa.ac.id/index.php/histogram/index

Histogram : Jurnal Pendidikan Matematika 4(1), 2020, 151 - 162

\title{
PENGGUNAAN UBIN ALJABAR UNTUK MENINGKATKAN KEMAMPUAN ALJABAR SISWA KELAS VII
}

\author{
Siti Rahmah ${ }^{1 *}$, Deshinta P.A.D. Argaswari ${ }^{2}$ \\ ${ }^{1,2}$ Sampoerna University \\ * Corresponding Author. Email: siti.rahmah@my.sampoernauniversity.ac.id \\ Received: 1 Maret 2020; Revised: 27 Maret 2020; Accepted: 30 Maret 2020
}

\begin{abstract}
ABSTRAK
Siswa kelas VII mengalami kesulitan dalam mentransformasikan pengetahuan mereka dari konkret ke abstrak. Hal ini berakibat siswa tidak menyadari bagaimana penggunaan konsep aljabar dalam kehidupan. Kesulitan ini tentunya berpengaruh terhadap kemampuan aljabar siswa. Penelitian ini menelaah bagaimana penggunaan ubin aljabar sebagai alat manipulasi yang bertujuan untuk meningkatkan kemampuan aljabar. Metode yang digunakan dalam penelitian ini adalah penelitian tindakan kelas yang bertujuan untuk mengetahui strategi pembelajaran ubin aljabar dalam meningkatkan kemampuan aljabar siswa. Data dikumpulkan menggunakan pengamatan, wawancara, dan tes terhadap 36 siswa kelas VII SMP 166 Jakarta. Hasil dari penelitian ini menunjukkan bahwa penggunaan ubin aljabar meningkatkan kemampuan aljabar siswa. Kemampuan aljabar berdasarkan kriteria Kieran meningkat masingmasing pada kemampuan transformasional dari penelitian pendahuluan ke siklus kedua meningkat sebesar 42,23\%, kemampuan generasional meningkat 40,27\%, dan kemampuan metaglobal sebesar $58,33 \%$
\end{abstract}

Kata Kunci: Ubin Aljabar, Kemampuan Aljabar, PTK

\section{ABSTRACT}

Grade VII students are struggling in transforming their knowledge from concrete to abstract. It makes them not realize the use of algebra concepts in their life. The struggling also impacted to student's performance in learning algebra. This study examined the use of algebra tiles to increase student's performance in algebra as a manipulation tool in involving them in algebraic activities. The method used for this study is classroom action research who has the purpose to discover the strategies to increase algebraic performance. The data was collected by observations, interviews, and tests from 36 Grade VII Students of SMP 166 Jakarta. The result of this study shows that by using algebra tiles, student's performance in algebra is increased. Based on Kieran's criteria of algebraic performance, the transformational ability from preliminary into cycle 2 is increased for about 43,23\%, the generational ability is increased about 40,27\%, and meta-global ability is increased about $58,33 \%$.

Keywords: Algebra Tiles, Algebraic Performance, CAR

How to Cite: Rahma, S., \& Argaswari, D, P, A, D. (2020). Penggunaan Ubin Aljabar Untuk Meningkatkan Kemampuan Aljabar Siswa Kelas VII, 4(1), 151 - 162, doi: http://dx.doi.org/10.31100/histogram.v4i1.574

Permalink/DOI: http://dx.doi.org/10.31100/histogram.v4i1.574

\section{PENDAHULUAN}

Aljabar adalah salah satu topik matematika di sekolah yang juga berhubungan dengan konteks kehidupan siswa sehari-hari. Aljabar adalah topik yang mengajari tentang teori bilangan, operasi hitung, geometri dan pengukuran, matriks dan trigonometri pada jenjang Sarjana. Pada dasarnya, aljabar adalah studi tentang cara dan metode memanipulasi

Copyright $@$ 2020, THE AUTHOR (S). This article distributed under the CC-BY-SA-license. 


\section{Histogram: Jurnal Pendidikan Matematika, 4 (1), 2020 - 152 Siti Rahmah $^{1 *}$, Deshinta P.A.D. Argaswari ${ }^{2}$}

angka dan simbol. Aljabar biasanya berkaitan dengan ekspresi, operasi, pemecahan sistem persamaan, dan menemukan nilai dari yang tidak diketahui. Dalam mempelajari aljabar dibutuhkan kemampuan untuk memahami simbol, operasi dan masalah. Kemampuan tersebut dieksplorasi dalam kemampuan aljabar yang mencakup keterampilan dalam memahami pola dan membuat generalisasi (Andriani, 2016)

Untuk meningkatkan kemampuan aljabar, siswa perlu mentransformasikan pemahaman mereka dari aritmatika ke aljabar. Kemampuan aljabar juga terdiri dari beberapa kemampuan dalam memahami simbol dan operasi aljabar. Tetapi itu menjadi masalah ketika siswa berjuang dalam menafsirkan simbol-simbol seperti makna variabel, koefisien dan konstan dalam ekspresi aljabar (Yunita et al., 2015). Seperti halnya, siswa membutuhkan penggunaan konsep aljabar ketika mereka membeli sebuah apel jika yang diketahui adalah total harga dari 4 apel. Siswa seharusnya menggunakan operasi aljabar untuk mengetahui harga dari satu apel tersebut dengan mulai membuat model matematikanya. Model matematika dari situasi tersebut bisa dituliskan $4 \mathrm{x}=12.000$ yang mana x menunjukkan sebuah apel. Seharusnya, kedua ruas tersebut dibagi 4 agar siswa bisa mendapat harga sebuah apel nya. Itulah hal yang tidak dipahami banyak siswa arti variabel x dalam contoh situasi tersebut dan mereka memulainya dengan ketidakmampuan menginterpretasikan model matematika dalam bentuk aljabar (Karuniawati, 2016).Berdasarkan NCTM dinyatakan bahwa siswa menemukan masalah serius dalam belajar aljabar ketika menjadi abstrak karena aljabar kurang konkret bagi siswa (NCTM, 2000). Dengan demikian kondisi dapat berdampak pada kemampuan siswa dalam belajar aljabar.

Berdasarkan Kieran (2004) menyatakan bahwa siswa kesulitan dalam belajar aljabar karena terdapat pemisahan antara belajar aritmatika dan belajar aljabar. Siswa hanya terbiasa mengoperasikan aritmatika yang berfokus pada perhitungan tetapi tidak cenderung melihat aspek relasional dari operasi. Dengan demikian, berdampak pada kemampuan aljabar yang mana siswa mendapatkan kesulitan dalam memahami hubungan antara simbol (variabel) dan angka. Ada beberapa kesulitan dengan transisi dari aritmatika ke aljabar, beberapa di antaranya adalah (a) dalam beberapa masalah atau pertanyaan, siswa tidak hanya menjawabnya hanya dengan menghitung operasi, tetapi mereka juga perlu mengekspresikan model matematika yang mewakili masalah. Misalnya, masalah membeli apel, di mana 4 apel sama dengan 12.000, dan untuk menemukan harga apel maka perlu operasi aljabar. Itu juga perlu diekspresikan dalam model matematika seperti 4x = 12.000 (seperti penjelasan pada paragraf sebelumnya); (b) perbedaan antara simbol yang 


\section{Histogram: Jurnal Pendidikan Matematika, 4 (1), 2020 - 153 Siti Rahmah ${ }^{1 *}$, Deshinta P.A.D. Argaswari}

digunakan baik dalam aljabar dan aritmatika. Hal ini dapat dilihat dari penggunaan tanda “" yang dalam aritmatika berarti makna yang lebih luas, tetapi dalam aljabar artinya setara atau setara; (c) penggunaan variabel (alfabet) dan angka dinyatakan dalam ekspresi aljabar yang sama dan perlu aturan untuk melakukan operasi. Misalnya, operasi penambahan aljabar dari tidak dapat ditambahkan karena istilah yang berbeda, dan itu menunjukkan bahwa 2, $\mathrm{x}$, dan 3 terdiri dalam satu ekspresi yaitu $2 \mathrm{x}+3$.

Masalah kemampuan aljabar siswa dalam aljabar juga terjadi di SMP 166 Jakarta yang berlokasi di Jakarta Selatan. Siswa kelas tujuh di sekolah ini mengakui kesulitan mereka dalam belajar aljabar. Berdasarkan hasil tes pada pra-penelitian yang dilakukan peneliti sebelum penelitian tindakan kelas, data menunjukkan bahwa kemampuan aljabar siswa untuk kemampuan transformasional hanya mencapai 43, 29\%. Untuk kemampuan generasi mencapai 44, 44\%, dan untuk kemampuan meta-global mencapai 23, $61 \%$. Pengamatan juga menunjukkan bahwa siswa masih bertanya-tanya apa itu aljabar dan untuk apa aljabar itu. Selain itu, beberapa siswa juga bertanya tentang menggunakan variabel dalam matematika terutama dalam aljabar. Meskipun, ketika guru mencoba untuk memperkenalkan operasi penjumlahan dan pengurangan aljabar, siswa terlihat bingung untuk membedakan istilah mana yang sejenis dan tidak sejenis.

Pentingnya mempelajari aljabar untuk siswa kelas tujuh karena mereka dapat mencapai beberapa keterampilan seperti mampu mewakili dan menentukan berbagai pola simbol dalam ekspresi aljabar; mampu membandingkan dan menghubungkan berbagai bentuk operasi aljabar dan hubungannya; mampu mengidentifikasi fungsi dan persamaan dengan operasi aljabar (NCTM, 2000). Untuk mencapai keterampilan dalam mempelajari aljabar, guru dapat menggunakan alat manipulasi dalam mengajar aljabar untuk meningkatkan siswa dalam melakukan aljabar. Menggunakan manipulasi membuat guru memastikan bahwa siswa mereka dapat memahami hubungan antara alat yang digunakan dan konsep aljabar. Selain itu, menggunakan manipulatif akan melatih pemikiran siswa untuk mengidentifikasi hubungan antara ide-ide manipulatif dan ekspresi aljabar yang dipelajari, seperti variabel dan bagaimana menyelesaikan operasi aljabar (Castro, 2017).

Salah satu alat manipulasi untuk mempelajari aljabar yang dapat digunakan oleh guru untuk mengajar aljabar adalah ubin aljabar. Ubin aljabar adalah alat peraga persegi dan persegi panjang yang mewakili simbol yang digunakan dalam aljabar. Ubin aljabar adalah cara visual dan praktis bagi siswa untuk mengeksplorasi konsep baru dalam aljabar sebagai pengantar pembelajaran (Michael \& Anugwo, 2016). Oleh karena itu, dalam penelitian ini, alat manipulasi yang merupakan ubin aljabar mungkin dapat membantu 


\section{Histogram: Jurnal Pendidikan Matematika, 4 (1), 2020 - 154 Siti Rahmah ${ }^{1 *}$, Deshinta P.A.D. Argaswari ${ }^{2}$}

meningkatkan kemampuan aljabar siswa. Tujuan dari penelitian ini adalah penggunaan alat manipulatif dalam bentuk ubin aljabar akan meningkatkan kemampuan aljabar siswa kelas VII.

\section{METODE PENELITIAN}

Metode penelitian yang digunakan dalam penelitian ini adalah penelitian tindakan kelas (PTK). PTK bertujuan untuk mengembangkan inovasi pembelajaran serta merupakan bentuk refleksi yang bertujuan untuk meningkatkan rasionalitas dan praktek pembelajaran (Kusumah \& Dwitagama, 2009). Hopkins menyatakan bahwa PTK dilakukan dengan rutinitas guru membuat rencana pembelajaran, mempraktekkan pembelajaran dan interaksi dengan siswa, lalu melakukan refleksi (Argaswari, 2018). Dalam PTK ini, peneliti sebagai guru akan memberikan pembelajaran aljabar dengan menggunakan alat manipulasi yaitu ubin aljabar. Peneliti akan melakukan beberapa siklus penelitian hingga hasil kemampuan aljabar siswa meningkat. Pada setiap siklus dilakukan empat tahap berikut: 1) perencanaan, 2) implementasi, 3) pengamatan, dan 4) refleksi (Hopkins, 2008). Pada setiap siklus akan dikumpulkan data kemampuan aljabar siswa dengan menggunakan tes, wawancara, dan pengamatan.

\section{A. Tempat dan Waktu}

PTK dalam penelitian ini dilakukan di SMP 166 Jakarta dengan melibatkan 36 siswa kelas VII sebagai populasi penelitian. Populasi terdiri dari 22 siswa perempuan dan 14 siswa laki-laki. Selanjutnya untuk mendapatkan data yang lebih detail mengenai perkembangan kemampuan aljabar, diambil 6 subjek penelitian yang terdiri dari 2 siswa yang memiliki kemampuan aljabar tinggi, 2 siswa dengan kemampuan sedang, dan 2 siswa dengan kemampuan rendah. Kemampuan aljabar ditentukan berdasarkan tes yang disusun menggunakan definisi kemampuan aljabar berdasarkan Kieran.

Penelitian yang menggunakan ubin aljabar untuk meningkatkan kemampuan aljabar ini dilakukan selama 6 bulan dari mulai tahap persiapan pada Juli 2019 sampai dengan analisis hasil pada Desember 2019. Berikut adalah tahapan penelitian yang dilakukan 1) penelitian pendahuluan yang bertujuan untuk meneliti permasalahan yang timbul di kelas, proses pembelajaran, cara mengajar guru, karakteristik siswa, dan mengumpulkan data kemampuan aljabar siswa, 2) pra-siklus dilakukan dengan peneliti aktif terlibat menjadi guru untuk mengajarkan materi aljabar sesuai dengan gaya mengajar guru sebelumnya, 3) siklus 1 dilakukan dengan menggunakan ubin aljabar dalam

menjelaskan konsep aljabar, dan 4) siklus 2 dilakukan dengan melakukan pembelajaran 


\section{Histogram: Jurnal Pendidikan Matematika, 4 (1), 2020 - 155 Siti Rahmah $^{1 *}$, Deshinta P.A.D. Argaswari ${ }^{2}$}

sesuai dengan refleksi siklus 1 . Siklus akan diulang hingga mencapai tujuan yaitu meningkatnya kemampuan aljabar siswa. Pada PTK ini, kemampuan aljabar siswa telah meningkat pada siklus 2 sehingga penelitian berhenti pada siklus 2 .

\section{B. Instrumen Penelitian}

1. Tes

Tes dilakukan sebanyak tiga kali yaitu pra-tes pada penelitian pendahuluan, postes pada siklus 1, dan pos-tes pada siklus 2. Ketiga tes dikembangkan untuk mengetahui kemampuan aljabar siswa dengan menggunakan definisi dan kriteria kemampuan aljabar oleh Kieran yaitu kemampuan transformasional, kemampuan generasional, dan kemampuan meta-global. Lembar tes yang dikembangkan kemudian dicek kesesuaiannya dengan tujuan penelitian oleh ahli yang terdiri dari 2 dosen matematika dan 1 guru matematika. Selanjutnya setelah dinyatakan valid, lembar tes diuji cobakan ke siswa-siswa kelas 7 yang bukan merupakan partisipan penelitian. Hasil dianalisis menggunakan SPSS, dan didapatkan nilai Cronbach Alpha 0,795 untuk keseluruhan tes.

\section{Wawancara}

Wawancara bertujuan untuk melakukan konfirmasi terhadap kemampuan aljabar siswa. Wawancara dilakukan dengan menggunakan panduan semi terstruktur dengan topik wawancara adalah hasil tes siswa. Wawancara dilakukan dengan menggnakan lembar wawancara semi terstruktur berisi pertanyaan untuk menguji keajegan jawaban siswa pada tes. Lembar validasi disahkan oleh tiga orang validator terdiri dari 2 dosen matematika dan 1 guru matematika.

3. Pengamatan

Pengamatan dilakukan pada setiap sesi penelitian tindakan kelas. Pengamatan melibatkan dua orang pengamat lain. Pada setiap akhir sesi peneliti dan pengamat akan mendiskusikan hasil pengamatan pada setiap sesi dengan topik utama perkembangan kemampuan aljabar siswa. Lembar pengamatan diadaptasi dari petunjuk observasi kelas (Sugiyono, 2012). Lembar pengamatan kemudian dicek kesahihannya oleh 3 orang validator terdiri dari 2 dosen matematika dan 1 orang guru matematika. Berdasarkan hasil validasi, terdapat beberapa item yang perlu diperbaiki. Setelah diperbaiki, lembar pengambaran dikatakan valid oleh ketiga validator.

\section{Indikator Penelitian}

Dalam mencapai tujuan penelitian, terdapat tiga kategori pencapaian indikator peningkatan kemampuan aljabar berdasarkan Kieran yaitu 


\section{Histogram: Jurnal Pendidikan Matematika, 4 (1), 2020 - 156 Siti Rahmah $^{1^{*}}$, Deshinta P.A.D. Argaswari ${ }^{2}$}

1. Kemampuan Transformasional

Kemampuan aljabar siswa pada kategori kemampuan transformasional meliputi kemampuan untuk menjabarkan bentuk aljabar, melakukan operasi aljabar, melakukan faktorisasi aljabar, dan menyederhanakan ekpresi aljabar.

2. Kemampuan Generasional

Kemampuan generasional dikuasai siswa apabila siswa mampu membuat bentuk aljabar dari sebuah permasalahan sederhana yang diberikan, dan siswa mempu mempresentasikan permasalahan menggunakan persamaan aljabar.

3. Kemampuan Meta-Global

Kemampuan meta-global meliputi kemampan siswa untuk menganalisis perubahan, hubungan aljabar, mengeneralisasikan bentuk aljabar, memodelkan masalah aljabar, dan menyelesaikan permasalahan aljabar.

\section{HASIL DAN PEMBAHASAN}

\section{A. Hasil Penelitian}

Berdasarkan penelitian yang telah dilakukan, maka hasilnya dapat dipaparkan sebagai berikut:

1. Pra Penelitian

Kinerja siswa saat pra penelitian menunjukkan kategori yang cukup rendah berdasarkan kemampuan aljabar Kieran. Berdasarkan hasil pre-test yang dilakukan oleh siswa telah didapat bahwa sebesar 43, 29\% siswa mencapai kemampuan transformasional, 45, 83\% kemampuan generasional, dan 23, 61\% kemampuan meta-global. Bahkan, berdasarkan hasil wawancara dengan subjek penelitian dalam menyelesaikan soal tersebut beberapa diantaranya masih bingung dalam membedakan simbol antara koefisien dan konstanta.

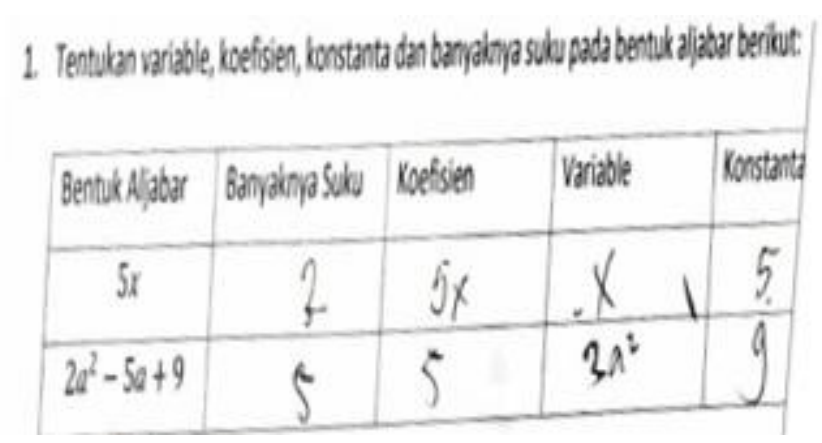

Gambar 1. Hasil tes siswa tentang membedakan koefisien dan konstanta 


\section{Histogram: Jurnal Pendidikan Matematika, 4 (1), 2020 - 157 Siti Rahmah ${ }^{1 *}$, Deshinta P.A.D. Argaswari ${ }^{2}$}

Untuk melakukan operasi aljabar juga dianggap membingungkan oleh subjek penelitian karena dalam bentuk aljabar terdapat variabel yang berbeda.

\section{Kumpulkan sukussuku sejenis dari persamaan berikut, kemudian sederhanakan $3 a+5+10+6 a+5 b$ \\ Jawab: $38+68+5+10+5 b$ \\ $=92+15+56$ \\ $: 19 d+206$}

Gambar 2. Hasil tes siswa tentang kemampuan membedakan variabel

Berdasarkan hasil observasi juga menunjukkan bahwa banyak siswa yang bingung dalam mengidentifikasi simbol-simbol pada bentuk aljabar. Bahkan, selama pembelajaran di menit ke 20 mulai ada beberapa siswa yang justru tidak fokus dalam mengikuti pembelajaran dan ada yang mengobrol dengan temannya dengan tidak memperhatikan guru.

2. Siklus 1

Proses pembelajaran pada siklus 1 , siswa menunjukkan keterlibatannya dalam pembelajaran bentuk aljabar. Bahkan saat diperkenalkan penggunaan ubin aljabar, banyak siswa yang ingin maju ke depan kelas dan menunjukkan representasi bentuk aljabarnya. Hasil observasi pertemuan pertama terlihat bahwa siswa sudah mampu mengidentifikasi simbol-simbol aljabar dengan membedakan bentuk ubin aljabar, seperti halnya siswa sudah bisa menyebutkan variabel dan koefisien pada bentuk 20x. Bahkan ketika diajak mengamati persoalan yang ada di buku, siswa terlibat membuat bentuk aljabar dari $20 x$ dengan menyusun blok. Siswa juga bisa membedakan mana suku sejenis dan tidak sejenis oleh karena nya siswa bisa melakukan operasi pada bentuk aljabar. Pertemuan kedua dan ketiga siswa juga sudah mulai terbiasa dan paham dalam membedakan simbol bentuk aljabar. Bahkan, siswa bisa melakukan operasi hitung aljabar dengan menunjukkan bagaimana cara menyusun blok dalam melakukan operasi penjumlahan, pengurangan, perkalian, dan pembagian. Berdasarkan hasil tes siklus 1 juga terlihat kinerja siswa dalam aljabar sudah mulai meningkat khususnya pada kemampuan transformasional yang mana siswa harus memahami simbol aljabar. Seperti bisa dilihat pada diagram berikut: 


\section{Histogram: Jurnal Pendidikan Matematika, 4 (1), 2020 - 158 Siti Rahmah ${ }^{1 *}$, Deshinta P.A.D. Argaswari ${ }^{2}$}

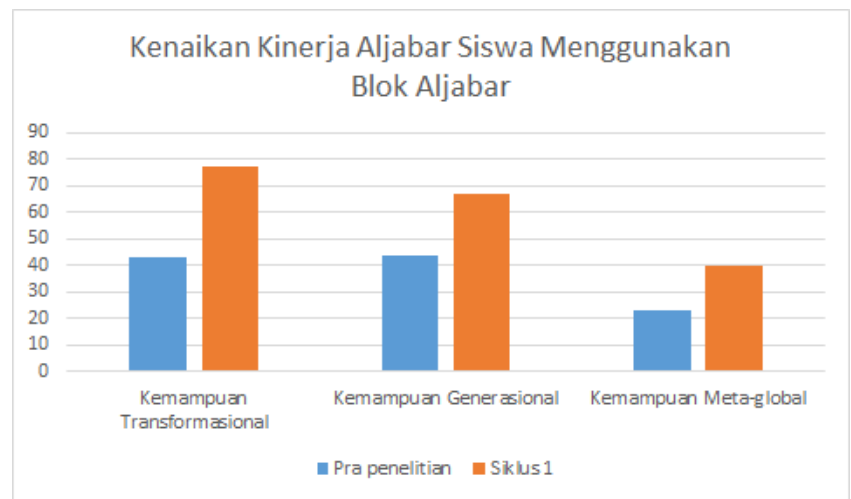

Gambar 3. Kenaikan kemampuan aljabar siswa dari pra penelitian ke siklus 1

Terlihat bahwa ketiga kemampuan tersebut mengalami peningkatan yang cukup signifikan. Pada kemampuan transformasional rata-rata hasil tes sebesar 77, 31\% dimana siswa sudah bisa mengidentifikasi simbol yang ada pada bentuk aljabar dan melakukan operasi hitung aljabar. kemudian peningkatan kemampuan generasional sebesar 67, 36\% bahwa siswa sudah bisa menuliskan bentuk matematika dalam bentuk aljabar dari representasi verbal dan menyadari bentuk kesetaraan pada persamaan bentuk aljabar. Untuk kemampuan meta-global, peningkatan yang terjadi sebesar 40, 27\% yang mana siswa mampu menyadari penggunaan konsep aljabar dalam menyelesaikan masalah.

Berdasarkan hasil refleksi pada pembelajaran tindakan siklus 1 segala kekurangan yang terjadi akan diperbaiki dalam siklus 2. Kekurangannya antara lain adalah: (1) Kurangnya latihan soal terkait operasi aljabar. Ini juga mengacu pada kekurangan dalam kemampuan transformasional dan generasional. Beberapa siswa masih kesulitan dalam melakukan operasi pembagian yang berhubungan dengan bentuk aljabar berpangkat lebih dari dua. Hal tersebut juga karena beberapa siswa masih belum mengerti untuk melakukan pembagian bilangan bulat; (2) Kurangnya keterlibatan siswa dalam kegiatan aljabar untuk menyelesaikan masalah. Ini cocok dengan defisiensi kemampuan meta-global. Siswa tidak terbiasa dengan masalah yang berkaitan dengan konsep aljabar dan itu membuat mereka tidak terlibat dalam kegiatan kelas untuk memecahkan masalah.

3. Siklus 2

Persiapan yang dilakukan oleh peneliti pada siklus 2 ini adalah: (1) Mengulas kembali pembelajaran pada siklus 1 mengenai operasi hitung aljabar, menuliskan bentuk matematika; (2) Menyajikan beberapa soal-soal yang berkaitan dengan masalah-masalah yang menggunakan konsep aljabar; (3) Mendorong siswa untuk menyelesaikan masalah dengan menggunakan ubin aljabar untuk menyelesaikannya dan menunjukkan cara penyelesaiannya. 


\section{Histogram: Jurnal Pendidikan Matematika, 4 (1), 2020 - 159 Siti Rahmah ${ }^{1 *}$, Deshinta P.A.D. Argaswari ${ }^{2}$}

Dalam siklus 2 ini, sebagian besar siswa dapat mencapai kemampuan transformasi di mana mereka dapat menentukan simbol aljabar. Mereka juga dapat melakukan operasi aljabar dan mendapatkan ide tentang hubungan variabel. Selain itu, siswa juga dapat membuat persamaan dan menulis persamaan dan ketidaksetaraan dari representasi verbal. Sebagian besar siswa juga dapat mencapai kemampuan meta-global di mana mereka menggunakan operasi aljabar untuk menyelesaikan masalah. Menariknya, beberapa siswa dapat menyadari penggunaan aljabar dan juga hubungan antara simbol-simbol dalam ekspresi.

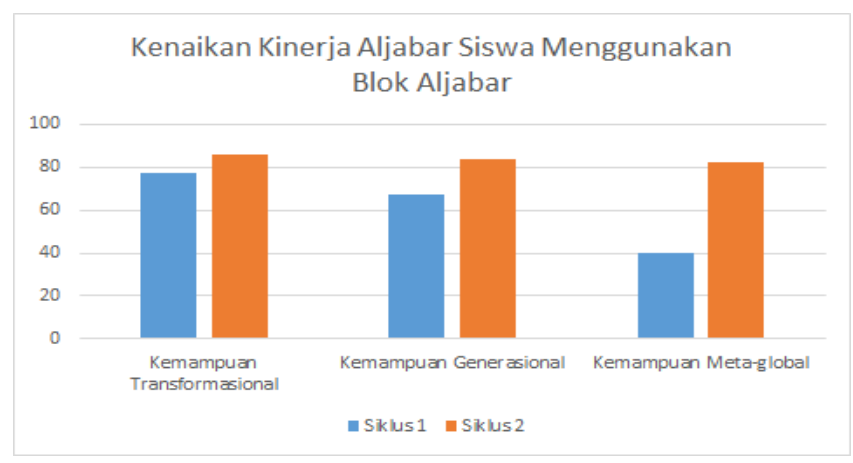

Gambar 4. Kenaikan kemampuan aljabar siswa dari siklus 1 ke siklus 2

Pada kemampuan transformasional rata-rata hasil tes sebesar $86,52 \%$ dimana siswa sudah bisa mengidentifikasi simbol yang ada pada bentuk aljabar dan melakukan operasi hitung aljabar. kemudian peningkatan kemampuan generasional sebesar 84, 71\% bahwa siswa sudah bisa menuliskan bentuk matematika dalam bentuk aljabar dari representasi verbal dan menyadari bentuk kesetaraan pada persamaan bentuk aljabar. Untuk kemampuan meta-global, peningkatan yang terjadi sebesar $81,943 \%$ yang mana siswa mampu menyadari penggunaan konsep aljabar dalam menyelesaikan masalah.

\section{B. Pembahasan}

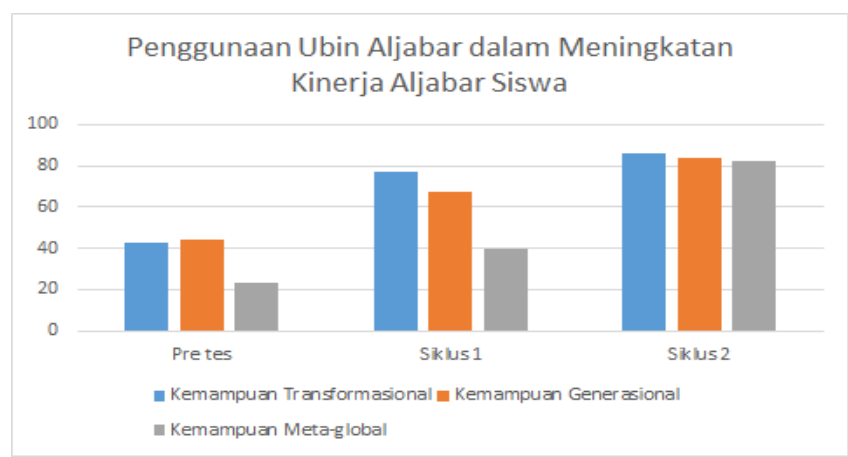

Gambar 5. Kenaikan kemampuan aljabar siswa 


\section{Histogram: Jurnal Pendidikan Matematika, 4 (1), 2020 - 160 Siti Rahmah $^{1 *}$, Deshinta P.A.D. Argaswari ${ }^{2}$}

Jika diperhatikan perubahan hasil tes dari pra penelitian, siklus 1 dan siklus 2, maka pembelajaran aljabar dengan menggunakan ubin aljabar berdasarkan aktivitas kemampuan Kieran ini mampu meningkatkan kinerja siswa kelas VII SMP 166 Jakarta. Peningkatan kinerja aljabar berdasarkan kemampuan Kieran juga dapat dilihat dari pra penelitian hingga siklus 1 dan siklus 2 seperti halnya kemampuan transformasional mengalami kenaikan sebesar 43, 23\%, kemampuan generasional sebesar 40, 27\%, dan kemampuan meta-global sebesar 58,33\%. Jika dilihat juga pada peningkatan di akhir siklus 2 dengan rata-rata kemampuan sebesar $84,39 \%$ yang mana sudah mencapai kriteria peningkatan kinerja aljabar sebesar $80 \%$.

Kinerja aljabar siswa meningkat karena alat manipulasi yaitu ubin aljabar yang diberikan tindakan pada siklus 1 dan siklus 2: (1) memperkenalkan ubin aljabar; (2) memberikan kesempatan bagi siswa untuk terlibat dalam belajar dengan membuat ekspresi aljabar, melakukan operasi aljabar, membuat persamaan persamaan, dan memecahkan masalah aljabar; (3) mempraktekkan masalah aljabar dikombinasikan dengan ubin aljabar; (4) melibatkan siswa dalam diskusi kelas. Menurut Caylan penggunaan ubin aljabar untuk belajar materi aljabar mampu mengajak siswa untuk memahami konsep abstrak dengan berpikir secara konkret (Caylan, 2018). Oleh karenanya, siswa lebih mudah memahami konsep koefisien dan konstanta setelah menggunakan ubin aljabar. Selain itu ubin aljabar adalah sebuah alat manipulasi yang dapat digunakan untuk mengeksplorasi dan mengekspresikan permasalahan matematika menjadi bentuk aljabar, sehingga siswa menjadi mudah memecahkan masalah menggunakan ubin aljabar (Saraswati et al., 2016)

Hal tersebut mengartikan bahwa hipotesis tindakan telah terjawab yaitu menggunakan ubin aljabar dalam pembelajaran aljabar pada siswa kelas VII SMP 166 dapat meningkatkan kinerja aljabar siswa dengan kemampuan berdasar Kieran.

\section{KESIMPULAN DAN SARAN}

\section{A. Kesimpulan}

Berdasarkan hasil dan diskusi penelitian ini, dengan menggunakan ubin aljabar dapat meningkatkan kemampuan aljabar berdasarkan kerangka kerja Kieran. Peningkatan terjadi dari penelitian pendahuluan menjadi siklus 1 dan siklus 2. Untuk kemampuan transformasional, peningkatan menunjukkan bahwa 43, 23\% siswa dapat menentukan simbol aljabar dan melakukan operasi aljabar. Peningkatan kemampuan generasi juga mencapai 40, 27\%. Dan peningkatan kemampuan meta-global meningkat 58, 33\%. Selain 


\section{Histogram: Jurnal Pendidikan Matematika, 4 (1), 2020 - 161 Siti Rahmah $^{1 *}$, Deshinta P.A.D. Argaswari ${ }^{2}$}

itu, hasil pengamatan juga menunjukkan bahwa siswa sudah terlibat dalam diskusi kelas dalam belajar aljabar dengan menggunakan kegiatan aljabar yang mengharuskan mereka untuk terlibat dalam kegiatan langsung dengan menggunakan ubin. Hasil wawancara juga menunjukkan peningkatan kinerja siswa dimana siswa sudah mencapai kemampuan 80\% dari kerangka kerja Kieran dalam menjawab tes dan mereka juga dapat menunjukkan keterampilan-keterampilan tersebut dengan baik.

\section{B. Saran}

Dalam melakukan penelitian di masa mendatang, peneliti harus lebih memperhatikan landasan teori yang mendukung studi mengenai keterampilan aljabar dan manipulasi pembelajaran. Saran praktis dalam penelitian ini bahwa peneliti harus memperhatikan alokasi waktu dalam implementasi penelitian yang melibatkan siswa pada beberapa aktivitas dalam belajar aljabar. Bahkan, peneliti bisa menyeleksi dengan baik pemberian soal-soal latihan yang harus diselesaikan oleh siswa yang sesuai dengan kadar pemahaman siswa itu sendiri.

\section{DAFTAR PUSTAKA}

Andriani, P. (2016). Penalaran Aljabar Dalam Pembelajaran Matematika. Beta Jurnal Pendidikan Matematika, 8(2),1-15.

Argaswari, D. P. A. (2018). Integrasi Sejarah Matematika untuk Meningkatkan Atensi Siswa. Indonesian Journal of Mathematics Education, 1(1), 59-65.

Castro, S. (2017). Algebra Tiles Effect on Mathematical Achievement of Students with Learning Disabilities. California State University.

Caylan, B. (2018). The Effects of Using Algebra Tiles on Sixth Grade Students' Algebra Achievement, Algebraic Thinking and Views about Using Algebra Tiles. Department of Elementary Science and Mathematics Education, Middle East Technical University,

Karuniawati, D. (2016). Kesulitan Siswa dalam Menyelesaikan Soal Operasi Bentuk Aljabar Pada Siswa SMP. Program Studi Pendidikan Matematika Fakultas Keguruan dan Ilmu Pendidikan Universitas Muhammadiyah Surakarta.

Kusumah, W., \& Dwitagama, D. (2009). Mengenal Penelitian Tindakan Kelas. Jakarta.

Michael, O. N., \& Anugwo, N. M. (2016). Card Games and Algebra Tic Tacmatics on 


\section{Histogram: Jurnal Pendidikan Matematika, 4 (1), 2020 - 162 Siti Rahmah $^{1 *}$, Deshinta P.A.D. Argaswari ${ }^{2}$}

Achievement of Junior Secondary II Students in Algebraic Expressions. International Journal of Evaluation and Research in Education (IJERE), 5(2), 93-100.

NCTM. (2000). Principle and Standards for School Mathematics. Reston, VA: National Council of Teachers of Mathematics.

Saraswati, S., Ilma, R., \& Somakim. (2016). Supporting Students ' Understanding of Linear. Journal On Mathematics Education, 7(1), 19-30.

Sugiyono. (2012). Metode Penelitian Pendidikan.Bandung: Alfabeta

Yunita, Hartoyo, A., \& Ijuddin, R. (2015). Kesulitan Siswa Dalam Menyelesaikan Soal Materi Operasi Hitung Pada Bentuk Aljabar Di MTS. Program Studi Pendidikan Matematika FKIP Untan. 